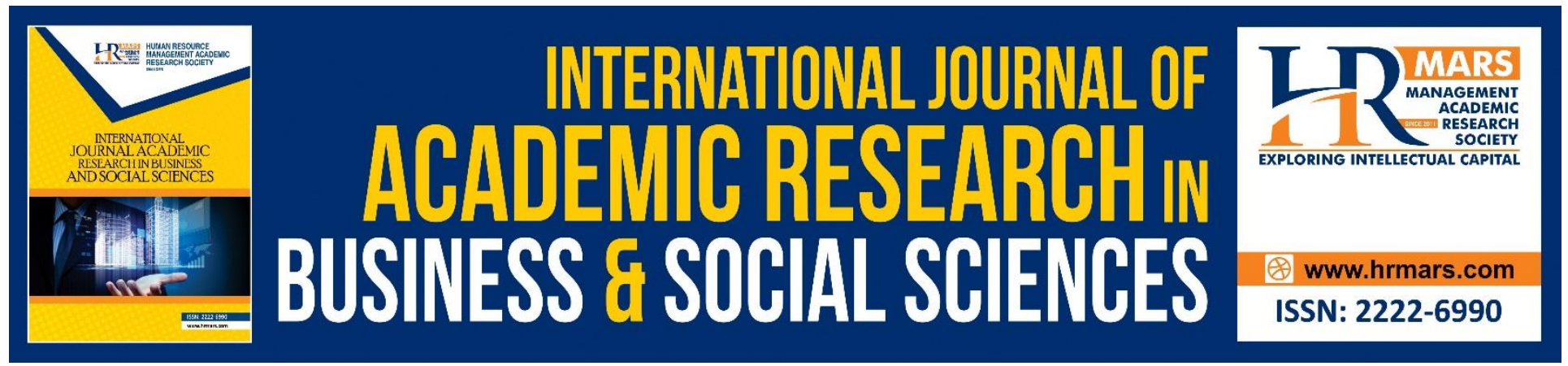

\title{
Intercourse during Menstruation: Islamic Ethics and Medical Views
}

Siti Fatimah Salleh, Nadhirah Nordin, Siti Khatijah Ismail, Tengku Fatimah Muliana Tengku Muda, Zurita Mohd. Yusoff, Ramlah Mat Ali, Rogayah Saeed Salameh Alqaraleh

To Link this Article: http://dx.doi.org/10.6007/IJARBSS/v8-i10/4726

DOI: $10.6007 /$ IJARBSS/v8-i10/4726

Received: 25 Sept 2018, Revised: 19 Oct 2018, Accepted: 26 Oct 2018

Published Online: 30 October 2018

In-Text Citation: (Siti Fatimah Salleh, Ismail, Muda, Yusoff, Ali \& Alqaraleh, 2018)

To Cite this Article: Siti Fatimah Salleh, N. N., Ismail, S. K., Muda, T. F. M. T., Yusoff, Z. M., Ali, R. M. \& Alqaraleh, R. S.S. (2018). Intercourse during Menstruation: Islamic Ethics and Medical Views. International Journal of Academic Research in Business and Social Sciences, 8(10), 212-217.

Copyright: (c) 2018 The Author(s)

Published by Human Resource Management Academic Research Society (www.hrmars.com)

This article is published under the Creative Commons Attribution (CC BY 4.0) license. Anyone may reproduce, distribute, translate and create derivative works of this article (for both commercial and non-commercial purposes), subject to full attribution to the original publication and authors. The full terms of this license may be seen

at: http://creativecommons.org/licences/by/4.0/legalcode

Vol. 8, No. 10, 2018, Pg. 212 - 217

http://hrmars.com/index.php/pages/detail/IJARBSS

JOURNAL HOMEPAGE

Full Terms \& Conditions of access and use can be found at http://hrmars.com/index.php/pages/detail/publication-ethics 


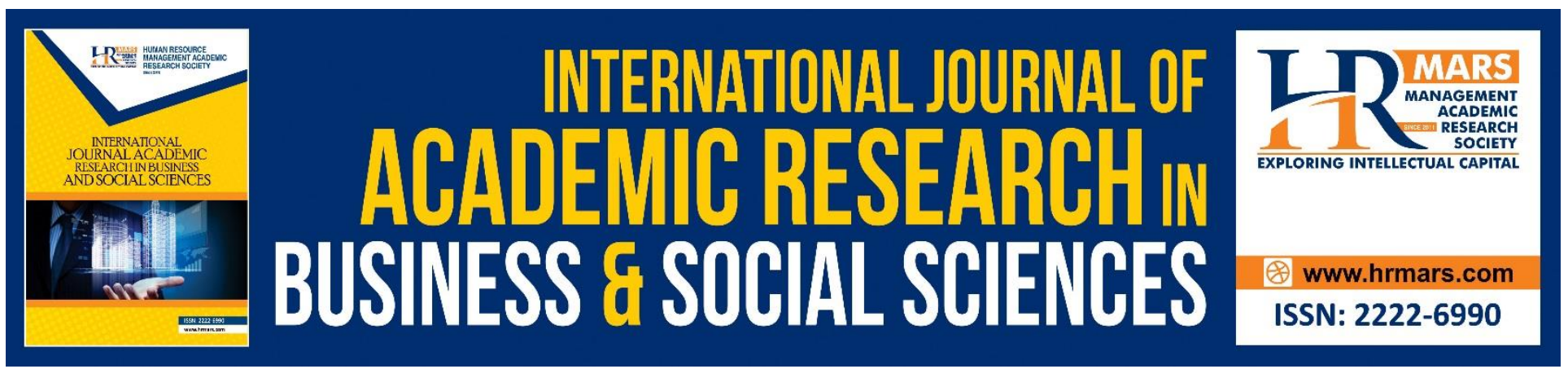

\title{
Intercourse during Menstruation: Islamic Ethics and Medical Views
}

\author{
Siti Fatimah Salleh, ${ }^{1}$ Nadhirah Nordin, ${ }^{2}$ Siti Khatijah Ismail, ${ }^{3}$ \\ Tengku Fatimah Muliana Tengku Muda, ${ }^{4}$ Zurita Mohd. Yusoff, ${ }^{5}$ \\ Ramlah Mat Ali ${ }^{6}$ \\ 1, 2, 3,4,5,6 Faculty of Islamic Contemporary Studies, Universiti Sultan Zainal Abidin, Gong Badak \\ Campus, Kuala Nerus, Terengganu, Malaysia. \\ Rogayah Saeed Salameh Alqaraleh ${ }^{7}$ \\ ${ }^{7}$ Univercity of Ha'il, Kingdom of Saudi Arabia.
}

\begin{abstract}
Menstruation is the periodic discharge of blood and mucosal tissue from the uterus and vagina. Islam places fair ethics in association with menstruating women, in contrast to the ethics introduced by the pre-Islamic (jahiliyyah) and Christian society. This article provides a comparative analysis of the ethics of association with menstruating women from the view of Islam and medicine. The data was collected through primary and secondary sources. The paper concludes that, adherence to the Islamic ethics of sexual intercourse during menstruation has a significant association with the scientific discovery on the risk factor resulting from an intercourse during menstruation.
\end{abstract}

Keywords: Intercourse, Menstruation, Islamic Ethics, Medical

\section{Introduction}

The arrival of Islam has liberated women from the value of depravity during the pre-Islamic (jahiliyyah) period. The history of menstrual taboo during the jahiliyyah such as practiced in Judaism showed that menstruating women were regarded as filthy and were kept isolated from any form of activity such as eating, drinking, clothing, bed and other daily activities. In contrast, the Christian community did not have any specific rules related to menstruation; men and menstruating women were freely allowed to engage in sexual relationship (Mansoor, n.d.). Hence, Islam as the religion of truth and mercy has outlined fair ethical principles suited for all human beings regardless of gender, race and age. Relatively, ethical principles related to sexual intercourse during menstruation is also introduced by the shari'a. 
Literally, menstrual blood is mainly composed of blood that comes out of a certain place at a certain amount and at a certain time, which is not caused by childbirth. The jurists ( fuqaha') of the four schools define menstruation as follows:

According to the Hanafi sect, menstruation means "discharge of blood from the womb, out of the inner genitals of a woman even in an theoretical way (hukmiy) which is not by reason of childbirth" (Abidin, n.d.). The Maliki sect defines menstruation as "yellowish or turbid discharge that comes out naturally - that is not due to childbirth or the torn hymen and others - even once " (al-Dusuki, n.d .; al-Hattab, 2003).

The Shafie sect defines menstruation as "natural blood that comes naturally out of the cervix of a woman after reaching the age of the puberty in a healthy state without any reason, and at certain times" (al-Kuji, n.d.; Al-Mawardi, 1994). While the Hanbali school defines menstruation as "natural blood discharged in a healthy state which is not due to childbirth, out of the cervix in a regular cycle at certain times" (al-Buhuti, 2003; Qudamah, 2004).

Islam gives great emphasis on ethical values in human life. In fact, Islam is essentially an ethical and moral code of conduct for human being based on divine commands and guidelines. The word "ethics" originates from the Greek word "ethos", which means "character, spirit and attitude of a group of people or culture" (Loeb, 1971). Islamic ethics is a science which deals with the ways to maintain virtues at their optimum level, which is to avoid wrongdoing and to do what is right and desirable (Nasir, 2003). Thus, this study discusses the ethical principles of sexual intercourse that must be abided by both husband and wife.

\section{Methodology}

This study adopted a qualitative approach based on primary and secondary sources through the method of document analysis. Classical and contemporary works were referred to complete the data collection for this study. Results from data collection were then analysed using content analysis method. Content analysis is a research technique for making replicable and valid inferences from texts to the contexts of their use (Krippendorff, 2004). The results of this analysis will discuss the sexual intercourse during menstruation from Islamic ethics and medical perspectives.

\section{Result and Discussion}

There are some ethics outlined in Islam when the husband wants to have sexual intercourse with the wife.

\section{Islamic Ethics on Intercourse during Menstruation}

First:

Islam requires sexual intercourse while women are in a state of purity from menstruation or childbirth. The Qur'anic verse in surah al-Baqarah verse 222 mentions the time of restriction of sexual intercourse during menstruation. If other than that time, the law is required as the purpose of the word of God: "And they ask you about menstruation. Say, "It is harm, so keep away from wives during 
INTERNATIONAL JOURNAL OF ACADEMIC RESEARCH IN BUSINESS AND SOCIAL SCIENCES

Vol. 8, No. 10, Oct. 2018, E-ISSN: 2222-6990 C 2018 HRMARS

menstruation. And do not approach them until they are pure. And when they have purified themselves, then come to them from where Allah has ordained for you. Indeed, Allah loves those who are constantly repentant and loves those who purify themselves".

\section{Second:}

Husbands are prohibited from having sexual intercourse with the wife during menstruation. This ethic was agreed by the fuqaha (al-Marghinani n.d.; al-Kasani, 2000; al-Dusuqin.d,; al-Nawawi n.d.; alSyirbini n.d.; Qudamah, 2004; -Khin, 2000). This is based on the Quranic verses in surah al-Baqarah verse 222.

\section{Third:}

Islam allows husbands to enjoy the entire body of the womans during menstruation except between the navel and the knee (Mustafa, 2000).

\section{Fourth:}

Islam also prohibits a husband from having sexual intercourse with a wife who has no menstrual blood before performing a purification bath (ghus/). This ethics means a wife who has stopped her menstrual period or has passed the maximum period of menstruation and not yet performing a ritual bath, is prohibited from having sex with the husband. The Fuqaha had different opinions about law of intercourse with a wife who has no menstrual blood before performing a purification bath (ghusl). Part of the Hanafi school of jurisprudence said husband is allowed to have sexual intercourse with wife who has no menstrual blood before performing a purification bath (ghusl) with a condition that the menstrual blood must stop on the maximum period of ten days (Abidin, 1994). While the other said haram or prohibited to husband from having sexual intercourse with a wife who has no menstrual blood before performing a purification bath (ghusl) (Malik, Al-Hattab, Al-Ramli, Qudamah, 2004).

\section{Fifth:}

Islam asks the husbands to wait for their wife of purity from menstruation. This is based on Allah's word in the same sentence, means: "Therefore keep away from the woman (do not intercourse with your wife) In the future the menstrual blood".

\section{Sixth:}

It is not allowed for a man to have sexual intercourse with the wife during her menses, but the jurists differ in their opinion if the blood is other than black or red in colour, either in the beginning or at the end of the menstruation. The fuqaha' discuss the issue of determining the blood category by explaining that there are certain implications for blood color differences in determining menstruation, and in relation to that, it also determines the rulings on sexual intercourse during menstruation. The fuqaha' of four schools agree that black is the menstrual blood (al-Kasani, 2000; al-Sarkhasi, 1989), as well as red because red is the original color of blood. However, they disagreed on the rest of the colours to two views: 
i - Yellowish and orangish: both are considered as menstrual blood either in the early menstruation or at the end of the period of menstruation. This is according to the views of Abu Hanifah, Muhammad, al-Malikiyyah, al-Shafi'iyyah and al-Hanabilah (al-Kasani, 2000; al-Sarkhasi, 1989; alDardir.; al-Mawardi, 1994; Qudamah, 2004).

ii- If it occurs in the early menstruation, it is not recognized as menstruation. It will only be considered menstrual blood if it occurs at the end of the menstrual period according to the views of Abu Yusuf and Abi Thaur (al-Kasani, 2000; al-Sarkhasi, 1989; Qudamah, 2004).

Thus, according to this view, the husband is allowed to have an intercourse with his wife whose blood color is other than black and red in the early menstruation cycle. In this situation, the most preferable view in the determination of menstrual blood is the first view. Consequently, during the existence of the color, menstruating woman are obliged to abandon the things that are prohibited to her, including sexual intercourse.

\section{Seventh:}

Islam allows association between husband and wife in daily routine such as eating, drinking, sleeping and other activities.

\section{Eighth:}

Islam discourages isolating women or wives during their menses by separating their place of residence.

\section{Medical perspective on Intercourse during Menstruation}

Medicine proves the very same fact which Quran mentioned that menstruation is dirt. It also carries many disadvantages if it continues to be in the woman's body. Human bodies have two types of secretion that play an important role in their function. Secretion of digestive glands and all types of internal secretions that regulate the system in the body benefits the person's body. Meanwhile another secretion such as urine, feces, sweat and menstruation will harm the body and need to be removed from one's body because the secretion produces toxic substances (al-Duwairi, 2007).

It is medically proven that blood is the best environment for developing bacteria. Sexually transmitted infections can be transmitted from one person to another through menstrual blood. It is essential to avoid from having intercourse with menstruating women because doing so leads to bacteria entering female uterus, spreading inflammation in the urinary organs. It will cause painful during menstruation, anemia, endocrine injury and difficulty in pregnancy. All these conditions increase the chance of infection when having intercourse during menstruation. Thus, it shows that the menstrual flows is a form of cleansing for woman's body and play a role in protecting the body from toxic which will lead to harmful and greater danger (al-Duwairi, 2007). 
INTERNATIONAL JOURNAL OF ACADEMIC RESEARCH IN BUSINESS AND SOCIAL SCIENCES

Vol. 8, No. 10, Oct. 2018, E-ISSN: 2222-6990 ㄷ 2018 HRMARS

\section{Conclusion}

As a conclusion, the Islamic ethics associated with sexual intercourse during menstruation coincides with the discovery and explanation of science about the harm that will apply. Compliance with this ethics ensures the well-being and harmony of a marriage.

\section{Acknowledgement}

This project was funded by the Project Univercity Scheme (DPU) from UniSZA (UniSZA/2017/DPU/24). We would like to thank UniSZA for the financing and facilities provided.

\section{Corresponding Author}

Siti Fatimah Salleh, Faculty of Islamic Contemporary Studies, Universiti Sultan Zainal Abidin Malaysia. Email: sitifatimah@unisza.edu.my

\section{References}

Al-Buhuti, M.I. (2003). Kasysyaf al-Qina' 'an Matn al-lqna'. (Eds). Ibrahim, A. A. H.Al-Sa'udiyyah: Dar 'Alam al-Kutub.

Al-Dusuki, S.S. (n.d.). Hasyiah al-Dusuki 'ala al-Syarh al-Kabir. Dar Ihya' al-Kutub al-Arabi.

al-Duwairi, Z.N.A. (2007). Athar al-Mustajiddat al-Tibbiyah fi Bab al-Taharah. Jordan: Dar al-Nafaes. al-Kuji, A.H. (n.d.). Zad al-Muhtaj bi Syarh al-Minhaj. (Eds). Abdullah, I., Lubnan: Maktabah al'Asriyyah.

Al-Hattab, A.M. (2003).Mawahib al-Jalil Li Syarh Mukhtasar Khalil. Lubnan: Dar al-Kutub al'Ilmiyyah.

Al-Kasani, 'A. A. (2000). Bada'l al-Sana'i' fi Tartib al-Syara'i'. (Eds). Muhammad, 'A.Y. Lubnan: Dar Ihya' al-Turath al-Arabi.

Al-Marghinani, B.A. (n.d.). Al-Hidayah Syarah Bidayatul al-Mubtadi'. al-Maktabah al-Islami.

Al-Mawardi, A. A. (1994). Al-Hawi al-Kabir. (Eds). 'Ali Muhammad Mu'awadh. Lubnan: Dar al-Kutub al-'Ilmiyyah.

Al-Nawawi, A.M. (2001). Al-Majmu'. (Eds). Muhammad Najib al-Muti'I. Lubnan: Dar Ihya' al-Turath al-'Arabi.

Al-Ramli, S.M. (1984). Nihayah al-Muhtaj ila Syarh al-Minhaj.Lubnan: Dar al-Fikr.

Al-Syirbini, M.K. (n.d.). Mughni al-Muhtaj ila Ma'rifah Ma'ani Alfaz al-Minhaj. Luban: Dar Ihya' alTurath al-Arabi.

Abidin, A.A. (1994). Radd al-Muhtar 'ala al-Ddurri al-Mukhtar. Lubnan: Dar al-Kutub al-'Ilmiyyah.

Qudamah, M.A. (2004). Al-Mughni.(Eds). Muhammad Syarifuddin Khattab. al-Qaherah: Dar alHadis.

Abidin, M.A. (n.d.). Majmu'ah Rasa'il Ibnu Abidin. Lubnan: Dar Ihya'al-Turath al-Arabi.

Krippendorff, K. (2004). Content analysis:An Introduction to Its Methodology(2nd ed.). Thousand Oaks, CA: Sage.

Loeb, S. (1971). A Survey of Ethical Behavior in the Accounting Profession. Journal of Accounting Research, 9(2): 287-306.

Malik, A. (n.d.). Al-Mudawwanah al-Kubra. Mesir: Tib'ah al-Sa'adah.

Mansoor, I. (n.d.). Bicara Darah Wanita, Nine Over Tendot Biz: Negeri Sembilan, Malaysia. 
INTERNATIONAL JOURNAL OF ACADEMIC RESEARCH IN BUSINESS AND SOCIAL SCIENCES Vol. 8, No. 10, Oct. 2018, E-ISSN: 2222-6990 (C) 2018 HRMARS

Nasir, O. (2003). Christian and Muslim Ethics. Kuala Lumpur: Dewan Bahasa dan Pustaka, Mustafa, K., Mustafa, B. \& 'Ali, S. (2000). Al-Feqh al-Manhaji 'ala Mazhab al-Imam al-Syafie. Damsyiq: Dar al-Qalam. 